\title{
Kente Ulaşımı Sağlayan Binaların Kent İmajına Etkisi; Trabzon Örneği
}

\author{
Demet YILMAZ YILDIRIM
}

Karadeniz Teknik Üniversitesi, Mimarlık Fakültesi, Mimarlık Bölümü, 61080, Trabzon, Türkiye

(Alınış / Received: 01.03.2021, Kabul / Accepted: 11.09.2021, Online Yayınlanma / Published Online: 25.12.2021)

Anahtar Kelimeler

Kent Girişi,

Ulaşım Yapıları,

Kent İmajı,

Görsel Kimlik,

Trabzon.
Özet: Kent girișleri fiziksel bir geçiş alanı olmalarının yanında, kentlerin ilk izleniminin ve kimlik oluşumunda öncelikli mekânlardan biridir. Tarihte kent girişleri, savunma, simgeleme gibi farklı kaygılarla yapılan kent kapıları, giriş takları gibi çeşitlenirken, günümüzde havaalanları, terminaller, limanlar gibi ulaşım yapıları karşılama alanları olarak kent giriși görevi üstlenmektedir. Dolayısıyla ulașım yapıları bir taraftan kent kimliğine görsel katkı sağlarken, diğer taraftan kullanıcılar için farklı anlamlar içermektedirler. Bu yapılar yolcuların sadece fiziksel ihtiyaçlarının sağlandığı yerler değil aynı zamanda kentle ilk iletişimin kurulduğu ve kentle ilk karşslaşma noktaları ya da son izlenim yerleri olarak algısal açıdan etkili ve anı değeri yüksek bellek noktaları olarak tanımlanabilirler. Çalışmada tarihi Trabzon kent girişleri olarak kent kapıları ve günümüz kent girişleri olarak Trabzon terminali, havaalanı ve limanı ele alınmıştır. $\mathrm{Bu}$ yapıların biçimsel özellikleri, siluetteki görsel etkisi ve bu yapılara girişten çıkışa kadar yapılan hareket boyunca edinilen görünümlerin imaj değerlerinin objektif ve sübjektif değerlendirmeler sonucu ortaya konarak tartışılması amaçlanmıştır. Çalışma, Trabzon kent kimliğinde etkili ve öncelikli müdahale alanlarından biri olan ulaşım yapıları ve yakın çevrelerine ilişskin veri sağlaması açısından önemlidir.

\section{The Effects of the Buildings Providing Access to the City on the Image of the City; Trabzon Example}

\section{Keywords}

City Entrance,

Transport Buildings,

City Image,

Visual Identity,

Trabzon.

\begin{abstract}
The city entrances are one of the physical transition area, they are also priority places for being first impression and identity formation of cities. The city gates diversified like entrance, arches and etc. in history, which made with different aims such as city entrances, defense and symbolization in history. Today, transportation structures such as airports, terminals, and harbors serve as the entrance to the city and because of welcoming areas. Therefore, transportation structures contribute visually to the urban identity on the other hand, they have different meanings for users. These structures are not just places where the physical needs of the passengers are provided, but also they can be defined as perceptually effective and memorable points where the first communication with the city is established and as the first meeting points or last impression places with the city. In the study, city gates as Trabzon's historical city entrances and Trabzon transportation structures such as terminal, airport and port as today's city entrances that are considered. In this study, it is aimed to discuss the formal features of these structures, their visual effect on the silhouette and the image value of the views acquired during the movement from entrance to exit with objective and subjective evaluations. The study is important in terms of providing datas on transportation buildings and their near surroundings, which are one of the effective and priority intervention areas in Trabzon's urban identity.
\end{abstract}

\section{Giris}

Giriş, mimari anlamda bir yapıda içeri geçilen yer, methal, antre, edebiyatta bir eserin konusunu tanıtarak kolay kavranmasını sağlayan, bölüm olarak tanımlanır [1]. Giriş, hazırlık ve tanıtıcı niteliği olan bir yerdir ve sınırla ilişkilidir. Sınırlar gözlemciler tarafından ulaşım aksları gibi kullanılmayan doğrusal 
öğelerdir [2]. Ayrıca sınırlar, bazı noktalarında geçişler veren ve iki bölgeyi birbirinden ayıran duvarlar veya birleştiren bağlantı noktalarıdır. Sınırların geçildiği noktalar yeni bir alana varış, iki alan arasındaki geçiş ise "giriş" tanımlamaktadır.

Geçmişte girişler, kent kapıları, giriș takları gibi farklı şekillerde biçimlenmiştir. Kent kapıları, surlarla çevrilmiş tarihi kentlerde öncelikle kente kontrollü erişim sağlamak için yapılmıştı. Savunma, güvenlik, sağlık, ticaret, vergilendirme ve temsil gibi farklı ișlevleri de olan yerlerdi. Kent kapıları, kentin tören aksıyla, en geniş sokağıyla, meydanıyla veya meydanda yer alan dini yapısıyla ilişkili olabilirlerdi. Zamanla kentlerin, savunma, güvenlik gibi gereklilikleri azalmış, artan nüfus ile birlikte yeni alanlara duyulan ihtiyaç sonucu, kentlerin sınırları surların dışına doğru genişlemeye başlamıştır.

Günümüzde kent sınırları, kentin baskın karakterli fiziki, beșeri ve ekonomik özellikleriyle belirlenmektedir [3]. Geçmişteki kent kapıları yerini günümüzde kent tabelalarının belirttiği sınırlara ve giriş taklarına bırakmıştır. Farklı bir açıdan ulaşım yapıları, bir kenti diğer bir kente bağlayan bir varış noktası ve geçiş alanı olması açısından kent girişi özelliği tașımaktadırlar.

Kent kimliği, kent imajını etkileyen, her kente farklı ölçek ve yorumlarla kendine özgü nitelikler taşıyan, fiziksel, kültürel, sosyo-ekonomik, tarihsel ve biçimsel faktörlerle şekillenen, kentliler ve onların yaşam biçimlerinin oluşturduğu, sürekli gelişen ve sürdürülebilir kent kavramını yaşatan, geçmişten geleceğe uzanan büyük bir sürecin ortaya çıkarttığ anlam yüklü bütündür $[1,4,5]$. Günümüzde mimari yapılarda genellikle birbirine benzer malzeme ve teknolojiler kullanılarak, benzer mimari eğilimlerle mekanlar üretilmektedir. $\mathrm{Bu}$ nedenle günümüz kentlerinde yerel özgünlüklerinin oluşturduğu kent kimliklerinin giderek silikleştiği görülmektedir.

İnsan çevreyi kendi amaçları doğrultusunda seçmekte, sınıflandırmakta ve etkili olanları zihnine almaktadır. Tüm bunların sonucunda ise insanın zihninde bir resim (kent imajı) oluşmaktadır. Tasarımı, düzenlenişi, görünümü ve yapılarının mimari özellikleriyle, bir kentin insanda bıraktığı genel izlenim olarak tarif edilen kent imajı kavramını [6] Lynch kent yaşantısının kişilerde bıraktığ duyusal ve düşünsel izler olarak tanımlamıştır [1]. Bu açıdan kent imajı, insanlar, onların yaşam biçimleri ve kent mimarisi olarak hareket edebilen ve edemeyen her şeyin ortak devinimidir [7].

Bir imgenin oluşmasında öncelikli olarak nesnenin tanınması, diğerlerinden ayırt edilmesi gerekmektedir. Bu durum o nesnenin kimlikli olması anlamına gelmektedir. Bir mimari ürünün kimlikli olarak nitelendirilmesi için ürünün mevcut yapılardan farklı ve şaşırtıcı olması ve dikkat çekmesi gerekmektedir [8]. Norberg - Schulz bu farklılığı "Genius Loci (yerin ruhu)" kavramı ile bağdaştırarak mimari ürünün kendine özgü olan ve onu diğer kentlerden farklı kılan özelliğinin ürünün "yeri" olduğunu ifade etmiştir. Yer kavramının ise fiziksel, kültürel gibi birçok niteliği özellikle barındırdığını belirtmiştir [9]. Lynch bir nesnenin tanımlanmasını sağlayan ve ona kimlik kazandıran şeyin, o nesnenin diğer şeylerden daha kuvvetli ve canlı ya da tekil oluşuyla, en azından kendine has bir karakterle ayrılmış olmasına bağlı olduğunu ifade etmektedir [1]. Tekeli ise mimari bir ürünün kimlikli olması için yaşayan insanların orayı anlamlı hale getirmesi gerektiğini, bir yerin kimliksizleşmiş olması için artık o yerin orada yaşayanlar için olumlu anlamlar üreterek yaşam kalitesine katkıda bulunma özelliğini yitirmiş olması gerektiğini belirtmiştir (2).

Kent, kendisini biçimlendiren insana onu biçimlendirecek birçok farklı mesaj iletmektedir. Kentlerle karşılaşan insanlar o yerin kendilerine ne söylemekte olduğunu anlayabilecekleri görsel işaretler ararlar [10]. Dolayısıyla kentlerin fark edilmesi ve ayırt edilmesi kentin özgün, kimlikli mimarisi ile mümkün olmaktadır. Ayrıca bir yerin imaj oluşturması ancak gözlenen-gözlemci arasında gerçekleșen algılama sonucu gerçekleșmektedir [6]. Algılama; insanın, eylemde bulunduğu mekânla etkileşimi sonucu çevreden gelen uyarıcı etkilerin, duyu organları yardımı ile hissedilmesi ve kavranmasına ilişkin zihinsel bir olgudur. $\mathrm{Bu}$ olgu izleyici-yorumcu aracılığıyla gerçekleșen bir süreci tarif etmekte, çevre ile ilgili bilgilerin toplanması, organize edilmesi ve yorumlanmasını içermektedir [6]. İnsan duyuları ancak uyarıldıkları zaman çalışmaktadır [11]. Kentlerin imaj oluşturulmasında, kentlerin algılanması dolayısıyla kentsel elemanların insanın duyularını uyarması gerekir ki bunun için mekânlarının okunabilir olması ve çeşitlilik sunması önem taşımaktadır. Çeşitlilik, hatırda kalıcılı̆̆ı ve seçim olanağını sağlarken, etkilenme ve uyarımı da yüksek seviyelere çıkarmaktadır [12, 13]. Çeşitlilik farklı yapı stilleri, farklı formlar, işlevler ve farklı zamanlarda yapılmış olma (tarihi değeri olma) ile sağlanmaktadır [14]. Çeşitlilik bir düzen içerisinde olduğunda okunabilirlikle örtüşmekte $[15,16]$, görsel zenginliği, farklılı̆̆ı, yeniliği, ilgi çekiciliği ve akılda kalıcılığı beraberinde getirmektedir.

$\mathrm{Bu}$ açıdan ulaşım yapıları kente ilişkin ilk izlenimlerin oluştuğu, kent imajında öncelikli ve etkili mekânlar olmaktadır. Hatta kentler, kısa süreli geçişler nedeniyle sadece bu ulașım yapılarıyla ve çevreleriyle hatırlanır olmaktadır. Calıșmada tarihi Trabzon kent girişleri olarak kent kapıları ve günümüz kent girişleri olarak Trabzon terminali, havaalanı ve limanından oluşan Trabzon ulaşım yapıları ele alınmıştır. Ulaşım yapıları kent imajı açısından önemlidir, bu nedenle kentsel dönüșüm kapsamında öncelikli ele alınması gerekmektedir. Çalışma bu anlamda Trabzon kent imajının güçlenmesi açısından 
veri sağlamaktadır. Ayrıca çalışma ulaşım yapıları ile ilgili hem sübjektif hem de objektif değerlendirme yer vermesi nedeniyle önem taşımaktadır.

\subsection{Trabzon Tarihi Kent Kapıları ve Ulaşım Yapıları}

Trabzon'un ne zaman kimler tarafindan kurulduğu kesin olarak bilinmemekle birlikte, kentin bazı kaynaklarda M.Ö. 2000'li yıllarda, bazı kaynaklarda ise M.Ö. 756 da kurulduğu belirtilmektedir [17, 18, 19, 20]. Tarihte Trabzon kenti bir süre Perslerin egemenliği altında kalmıştır. M.Ö. 1 yüzyılda Roma İmparatorluğu topraklarına katılan kent, 4. yy sonunda ikiye bölünen Bizans İmparatorluğu olarak bilinen Doğu Roma İmparatorluğunun egemenliği altına girmiştir. Kent, Anadolu Selçukluları ve Moğollar tarafından kușatılmıș, 1461'de Fatih Sultan Mehmet zamanında Osmanlı topraklarına katılmıștır. 1923'ten günümüze ise Türkiye Cumhuriyeti'nin bir kenti konumundadır [21].

Fiziksel açıdan iki vadi arasında kurulan tarihi Trabzon kentinin ilk çekirdeği olan Yukarı Hisar, surlarla korunan bir tepe üstü yerleşmesidir. Yukarı Hisar bir taraftan Tabakhane ve Zağnos Dereleri tarafından çevrelenirken kalan kısımlarda kale duvarları ile korunmuștur. Zamanla Yukarı Hisar șeklini koruyamamıș Yukarı Hisarı kușatan bir Orta Hisar oluşmuştur. Aşağı Hisar ise Zağnos Köprüsü'nden bașlayıp batıya doğru uzanmakta ve Zağnos kulesinden kuzeye dönmektedir [22]. Trabzon tarihi kent girişleri, Trabzon kentinin ilk kurulduğu surlarla çevrili olan Trabzon Kalesi'nin Yukarı Hisar, Orta Hisar ve Aşağı Hisarı bölümlerini birbirine bağlayan ve ya bu bölümlerin sur dışına açılan kent kapıları olmaktadır. Savunma kaygısıyla yapılan bu kapılardan kente girilmektedir. Günümüzde bu kapıların çoğu kaybolmuştur. Kent kapılarına ilişkin bilgilere ise seyahatnamelerden ulaşılmaktadır. Seyahatnamelerde yer alan bilgilere göre ise tarihi yerleşmede kapı sayılarında ve isimlerinde farklılıklara rastlanmıştır.

Bıjışkyan'a göre kalenin üç adet iç, altı adet de çift olarak dış kapısı vardır [18]. Denizden başlayarak ilk kapı kuzeyde Moloz Kapısı, ikincisi batı tarafta Sotğa Kapısı, üçüncüsü yine batı tarafta Zağanos veya Zindan Kapısı, dördüncüsü güney tarafta Kule Kapısı'dır. Burada Yukarı Hisar'a açılan diğer bir kapı olan beşinci kapı doğuda Dabahane Kapısı doğuda denize yakın Pazar ve ya Mumhane Kapısı'dır [23]. Bryer ve Winfield haritası dikkate alındığında surların 7 tanesi sur dışına, biri sonradan kapatılmış, 2 tanesi Yukarı Hisar ve Orta Hisar'a ve ikisi Orta Hisar'dan Aşağı Hisar'a açılan toplam 11 demir kapısı bulunmaktadır [22, 24].

Aşık Mehmed, Yukarı Hisar kapıları için;“...kuzey duvarında Orta Hisar'a açılan bir kapı bulunmaktadır. $\mathrm{Bu}$ kalenin Trabzon kentinin dışına açılan kapısı yoktur. Güney tarafında küçük bir kapısı varsa da bu kapı kilitlidir, ancak ihtiyaç duyulduğunda açılır" [23]. Evliya Çelebi, “...kuzey duvarında Orta Hisar’a açılan bir kapı var. Dışarı kente çıkan kapı budur. Başka yoktur. Bir gizli kapısı var ise de daima kapalı durur, lüzumunda açlır..." [23]. Bıjışkyan, "kalenin zaptı esnasında lanetle kapatılmıș olduğu rivayet edilen tıkanmış ufak bir kapı"yı Bryer ve Winfield haritalarda kuzeybatı duvarı üzerinde gösterir. Feruhan Bey ise diğerlerinin aksine Yukarı Hisar'da güney taraftan Kuzgundereye inen kule kapısı denilen çift kapı olduğunu belirtir $[18,22]$.

Aşı Mehmed, Orta Hisarda 4 kapıdan bahsetmektedir; Bab-ı Yeni Cuma: "surun doğu duvarında kalenin Orta Hisar'a açılan kapısı yakınındadır",Bab-ı Debbağhane/Tabakhane: "bu kapıdan Tabaklar Çarşısı'na taştan yapılmış büyük bir köprü ile geçilir", Bab-ı Zindan: "bu kapıdan taştan yapılmış 3 ziralık kısmı ahşap kaplı büyük bir köprüden Bab-ı Zağanos'a geçilir ve Bab-1 Așağl Hisar: "surun kuzey duvarında Așağı Hisar'a açılır". Evliya Çelebi ise Orta Hisar'daki Yeni Cuma Kapısı: Orta Hisar'a açık olan kapısı yakınında, Debbağ Kapısı: aynı duvarın doğusunun sonunda, Zindan Kapısı: kalenin batısında bütün katiller, borçlular bu kale kulesinde hapis olunur, Așağı Hisar Kapısı: surun kuzey duvarından Aşağı Hisar'a açılır olmak üzere dört kapıdan bahseder.

Aşık Mehmed, Aşağı Hisar'da dört kapıdan Bab-ı Zağanos: "Bab-ı Zağanos ile Bab-ı Zindan arasında uzun bir köprü vardır.”, Bab-ı Sutha: “Adını kapısının ardında yaşayan Hristiyan mahallesinin adından alır.". Katip Çelebi'e göre Süthane Kapısı, Bab-ı Moloz, Bab-ı Mumhane kapının dișında balmumu işlenen Şemhane yer almaktadır. Aşık Mehmed burada Bıjışkyana göre Pazar Kapısını belirtmiştir [18]. Evliya Çelebi ise Așağı Hisar'da Zağanos Kapısı, Süthane Kapısı, Moloz Kapısı, Mumhane Kapısı olmak üzere dört kapıdan bahsetmektedir [23] (Şekil 1).

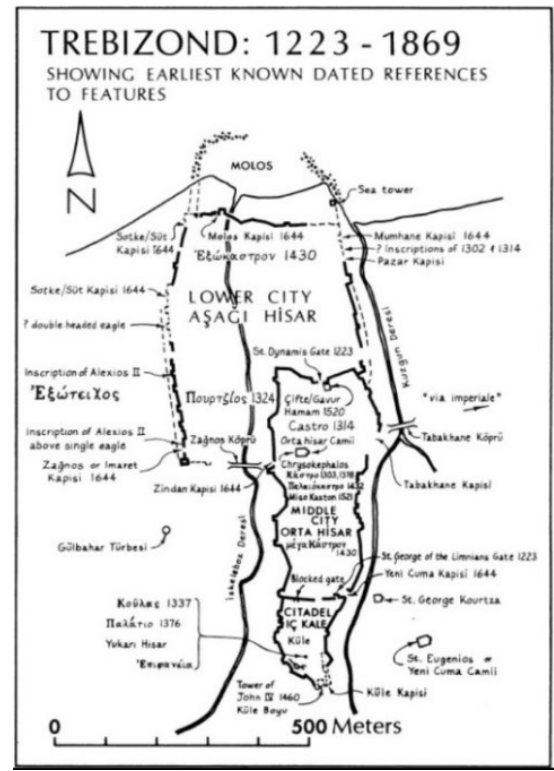

Şekil 1. Bryer ve Winfield haritasına göre kent kapıları 
Trabzon, batısında Giresun doğusunda Rize ve kuzeyinde Karadeniz ile çevrilidir. Karadeniz Bölgesi'nin önemli liman, ticaret ve kültür kentlerinden biridir. Tarihi İpek Yolu üzerinde yer alan Trabzon kenti, jeopolitik konumu sonucu bugün için Bağımsız Devletler Topluluğu (BDT) ülkelerinin Türkiye ve Avrupa bağlantısıdır [25]. Kentin coğrafi ve stratejik konumu sebebiyle kente karadan, denizden ve havadan ulaşım sağlanmaktadır. Kent girişleri açısından ulaşım yapıları değerlendirildiğinde;

- Trabzon, Doğu Karadeniz bölgesinin en büyük limanına sahip olup başta İran, Irak, Rusya ve Türk Cumhuriyetleri transit yolunun başlangıcında stratejik bir noktada yer almaktadır. Trabzon Limanı bu ülkelerin tüm Avrupa ve Dünya pazarlarına bağlanmasında kilit bir rol oynamaktadır $[26,27]$.

Bijişkyan limanın tarihte Xenophon'dan çok daha önceleri büyük bir gayret ve masrafla yapıldığını yazmaktadır. Eski müellifler kalenin kuzeyinde bulunan eski limanın muazzam bir yapıda olduğunu belirtmektedir. Texier ise Hadrian'ın gemilerin yanaşmasını tehlikeli gördüğü Güzel Saray kayalarının altında denize doğru uzanan taşlığın yanında bir yapay liman oydurduğunu belirtmiștir [27].

İlk Trabzon Limanı Moloz mevkiinde M. Ö. 117-119 yıllarında kayaların oyulması suretiyle oluşturulmuştur. Osmanlı İmparatorluğu döneminde eski rıhtım alanında kumandan Hasan Paşa tarafından bir liman ve rıhtım yapılmaya başlanmış, bu liman 1903 yılında Vali Mazhar Paşa tarafından tamamlanmıştır. $\mathrm{Bu}$ tarihlerde Trabzon Limanı Osmanlı İmparatorluğu'nun önemli limanından biri konumunda olmuştur. 1946'da temeli atılan yeni liman ise 1954 tarihinde tamamlanmıştır. 1978 yılına kadar durumunu koruyan Trabzon Limanının artan gemi trafiğine cevap verebilmesi için 1980'de başlayan yenileme çalışmaları 1990'da bitirilerek liman bugünkü konumuna getirilmiştir [28]. Liman, yolcu ve yük taşımacılığı olmak üzere iki önemli hizmeti yerine getirmektedir. 1960 yılına kadar bölgede denizyolu ile seyahatler oldukça fazla gerçekleşmiştir. Ancak bu tarihten sonra bölgenin karayolu ulaşım sisteminin gelișmesi ve havayolu ulașımının bașlaması nedeniyle deniz yolculuğuna olan ilgi azalmıştır. Günümüzde Trabzon limanına iç hat seferlerinin yanı sıra, turistik gemiler de sefer düzenlemektedir. Fakat limanda yük taşımacılığı yolcu taşımacılığına nazaran daha ön planda yer almaktadır [29].

- Trabzon Terminali Rize-Artvin-Batum-Tiflis ile Bağımsız Devletler Topluluğu ülkelerine, Gümüşhane-Bayburt-Erzurum ve GiresunOrdu-Samsun-Ankara ile İstanbul istikameti olmak üzere üç karayolu ağına hizmet vermektedir [30]. Trabzon Terminali'nin yapımından önce terminal hizmetleri Moloz Mevkii'nde ve Suluhan'da toplu şekilde, Taksim Meydanı'nda ise dağınık yazıhanelerde yürütülmüştür. Trabzon Belediyesi 1974'te Değirmendere Mevkiinde öncelikle bir otopark inșa ettirmiştir. Daha sonra otoparkin hizmet yetersizliği nedeniyle aynı yerde, kent merkezine $2 \mathrm{~km}$ uzaklıkta Trabzon Terminali yaptırmış ve terminal 1988'de faaliyete geçmiştir [25].

- Trabzon Havaalanı ise 1957'de inşa edilmiş ve 1995 tarihinde havalimanı statüsüne kavuşturulmuştur. Kent merkezine $6 \mathrm{~km}$ uzaklıkta, denize paralel olarak konumlanan havalimanından günümüzde birçok ulusal ve uluslararası kente, doğrudan uçuş sağlamaktadır [31] (Şekil 2).

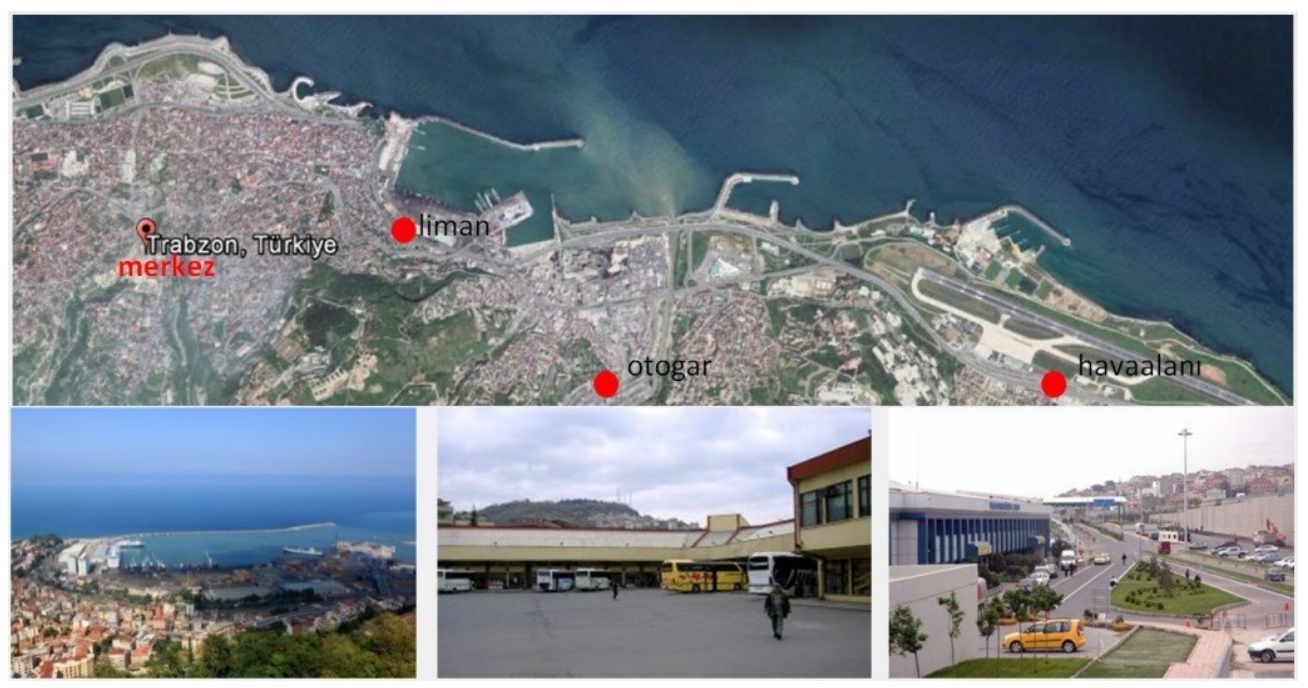

Şekil 2. Trabzon limanı, Trabzon terminali, Trabzon havaalanı [32, 33] 


\section{Materyal ve Metot}

Ulaşım yapıları, birer giriş kapısı niteliği taşıyan kente kimlik kazandırma potansiyeli ve kentlere dair ilk izlenimin oluşması açısından imaj değeri yüksek öncelikli yapılardır. Bu yapıların ve yakın çevresinin görsel kalitesi ve kullanıcıda oluşturduğu imaj değerinin tespiti kent kimliği açısından önemlidir. Çalışmada Trabzon ulaşım yapılarının ve yakın çevrelerinin görsel kalitesinin ve imaj değerinin tespiti amaçlanmıştır.

Çalışma iki aşamadan oluşmaktadır. İlk aşamada ulaşım yapılarının fiziksel özelliklerinin görsel kalitesi analiz edilmiştir. Ardından kullanıcıların bu mekânlardaki hareketleri sonucu edindikleri görünümlerin, imaj değeri incelenmiștir. Tüm bu analizlerde görsel analiz tekniği kullanılarak sübjektif bir değerlendirme yapılmıştır. Görsel analiz tekniği, tüm detayları gösteren fotoğrafların etkili ve özü çıkartılmış bir anlamı vurgulamaya yönelik birleştirilmesi olarak tanımlanmaktadır [34]. İmaj açısından önemli olan, çeşitlilik ve okunabilirlik kavramlarını sağlayan şekil-zemin, egemenlik, basitlik, tekillik, farklılık ve sinırların keskinliği kaliteleri belirlenmiştir. Öncelikle bu kaliteler bina ölçeğinde yapı ve yakın çevresi üzerinde analiz edilmiştir. Bina ölçeğinde bu kalitelerden hangilerinin güçlü ve zayıf olduğu incelenmiştir. Ardından her ulaşım yapısı için yolcunun indiği noktadan ulaşım yapısından ayrılıncaya kadar yapmış olduğu hareket boyunca 260 fotoğraf çekilmiştir. Bu fotoğraflar bir araya getirilerek her bir ulaşım yapısından 5'er adet olmak üzere toplam 15 siluet elde edilmiştir.

İkinci aşamada ise ulaşım yapılarının imaj değerinin kullanıcılar tarafından değerlendirilmesi hedeflenmiştir. Bunun için birçok ulusal ve uluslararası ulaşım yapılarını deniz stajları boyunca deneyimlemiş olan Deniz Ulaştırma İşletme Mühendisliği Bölümü'ndeki 130 öğrenciyle anket çalıșması yapılmıștır. Bu öğrencilerin 65 tanesi üçüncü, 65 tanesi ise dördüncü sınıfta yer almıştır. Ulaşım yapıları ve yakın çevrelerinin oluşturduğu görünümler PowerPoint sunum ile öğrencilere gösterilmiştir. Elde edilen veriler anlamsal derecelendirme ölçeğinde anlamsal farklılaşma cetveli kullanılarak değerlendirilmiştir. 11 sıfat çiftleri olduğu gibi (+) ve (-) yüklere göre faktörlere bağımlı ya da rastlantı tekniği ile karışık sıralanmıştır [35]. Her bir örneğe ait kriterler her deneğe ayrı ayrı uygulanarak 7'li Likert ölçekte belirlenen derecelendirmelere göre değerlendirme yapılmıştır. Son olarak öğrencilerden Trabzon Terminali, Havaalanı ve Limanı denince akıllarına gelen ilk șeyleri ifade etmeleri istenmiștir. Tüm bu veriler Trabzon ulaşım yapılarının ve yakın çevrelerinin görsel kalitesinin ve imaj değerinin tespiti amaciyla tartışılmıştır.

\section{Bulgular}

\subsection{Ulaşım Yapılarının Kentle Olan Fiziksel ve İşlevsel Îllişkisinin Değerlendirilmesi}

- Trabzon Terminali kentin doğu-batı yönünde büyümesiyle birlikte kent merkeziyle bütünleşmiştir. Terminal 1. Sahil Yolu üzerinde yer almaktadır. 1. Sahil Yolu kent ulaşım ağında kent merkezi ile sanayi bölgesi, üniversite ve alışveriş merkezi bağlantısı konumdadır. 2. Sahil Yolu'nun yapımı 1. Sahil Yolu'nun yoğunluğunu azaltmasına rağmen 1. Sahil Yolu bazı toplu taşıma araçları için halen Trabzon-Rize ve Trabzon-Erzurum bağlantısını sağlamaktadır. Terminalin bulunduğu bölge gerek kent içi gerekse kent dışı ulaşım aksının kesiștiği ya da kesintiye uğradı̆̆ alt merkezdir. Terminal binası bu konumu sonucu olarak imaj değeri yüksek olan bölgenin işaret öğelerinden biridir.

- $\quad$ Trabzon Limanı 1. Sahil Yolu ile 2. Sahil Yolu kesişiminde yer almaktadır. Ayrıca liman içerisinde farklı işlevlerde kullanılan tarihi binalar vardır. Bu binalar limanın kimlik değerini arttırmaktadır. Liman ve Çimento fabrikası bölgenin önemli işaret öğeleri olmaktadır. Ayrıca geçmişten günümüze bir liman kenti olarak tanınan Trabzon'da limanın, kentin tarihi fotoğraflarında da olduğu gibi kent kimliğinde de önemli bir yeri bulunmaktadır.

- Trabzon Havaalanı kentin büyümesi, adalet sarayının ve hastanenin kentin doğusuna taşınması ve bu bölgede yeni yerleşim alanlarının oluşması ile kent merkeziyle bütünleşmiştir. Havaalanı Trabzon-Rize bağlantısını sağlayan 2. Sahil Yolu üzerinde yer almaktadır. Gerek şehir içi gerekse şehirlerarası kullanımlarda yol boyunca algılanmaktadır. Ayrıca havaalanının deniz kenarında yer alması kent siluetinde etkili olmasını sağlamıştır. Havaalanı ve üniversite bölgenin tanınmasında önemli işaret öğeleri olmaktadır. Konumu ve kent ulaşım sistemleriyle ilişkisi açısından yapının imaj değeri yüksek olmaktadır (Şekil 3).

\subsection{Yapı-Yakın Çevrelerinin Biçimsel Değerlendirilmesi}

- İşlevleri gereği ulaşım yapıları biçimsel olarak geniş yer kaplamakta, bu nedenle de çevreye egemen, çevrede farklı ve tek olmaktadırlar. Havaalanının ve limanın deniz kenarında konumlanması bağlam açısından 


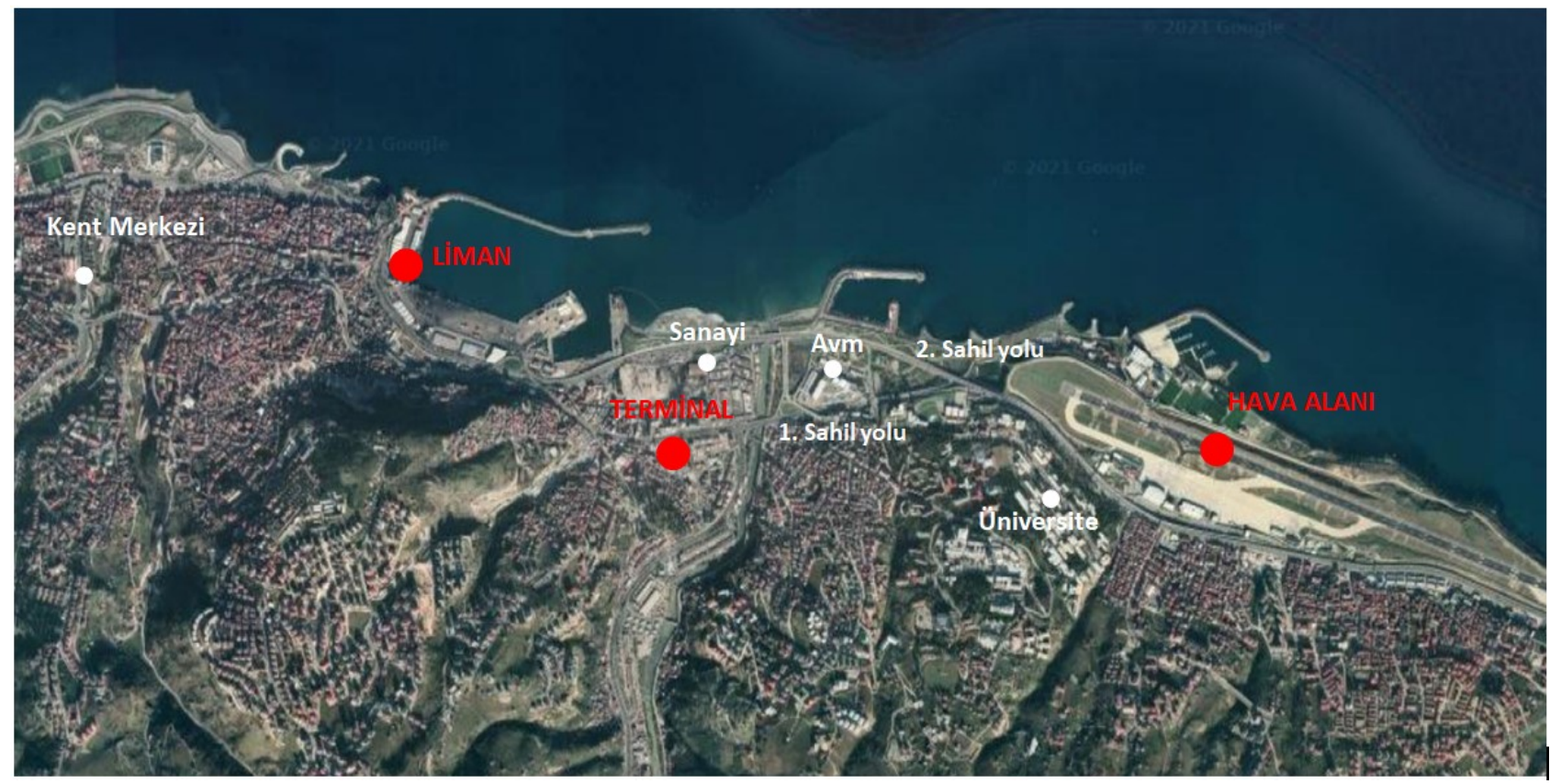

Șekil 3. Trabzon ulașım yapılarının konumları

yapıya özgünlük kazandırmıștır. Ayrıca limanda tarihi binaların olması limana ayırıcı bir nitelik de sağlamıştır.

- Biçimsel olarak bu yapıların hiçbiri diğer kentlerdeki ulaşım yapılarından farklı değildir. Bu yapılar birçok kente sıklıkla aynı malzeme ve teknolojilerin kullanıldığı, benzer mimari eğilimlerle üretilen imaj değeri zayıf yapılardır. Trabzon Terminali şekil-zemin etkisi açısından az kuvvetli bir yapıdır. Çevresindeki binalardan işlevinin gereği büyük olması açısından egemendir. Yapının tek olması ve sınırlarının keskin olması siluette okunabilirliğini sağlamakta, fakat yapı etkili bir imaj oluşumu açısından zayıf kalmaktadır. Trabzon Limanı şekilzemin etkisi açısından kuvvetli, olmakla birlikte kentsel dokuda işlev ve büyüklük bakımından tek olması açısından egemendir. Ayrıca tarihi binaların bu kompleks içinde yer alması limanın okunabilirlik ve imaj değerini attırmıştır. Trabzon Havaalanı ise denizin kenarında yer alması nedeniyle şekilzemin etkisi kuvvetli bir yapıdır. Havaalanının işlevi gereği boyut bakımından tek olması egemen olmasını sağlamıştır. Ayrıca yapının sınırlarının keskin olması ve siluetteki tekilliği okunabilirliğini kolaylaştırmıştır.

- Ulaşım yapılarının yakın çevreleri çarpık, niteliksiz ve yüksek yapılarla çevrelenmiștir.
Çevrelerinde etkili bir ișaret öğesi bulunmamaktadır.

- Çevre yapılarının üslup açıdan uyumsuzluğu, kat yükseklikleri ve büyüklükleri arasındaki oransızlık siluetlerde karmaşaya neden olmuştur. Özellikle havaalanı çevresindeki duvar oluşumu görsel açıdan negatif bir durum yaratmıştır.

Terminal binası ve havaalanının yakın çevresinde yeşil alan yok denecek kadar az ve kopuktur. Liman siluetlerinde ise diğer yapılara nazaran yeşil, biraz daha fazla ve sürekli olmaktadır fakat yetersizdir. Sonuç olarak tüm ulaşım yapılarının yakın çevrelerinde doğal çevre ile yapılı çevre bütünlüğü bulunmamaktadır (Tablo 1.2.3.4.5.6.).

\subsection{Hareket Boyunca Elde Edilen Görünümlerin Değerlendirilmesi}

Trabzon'daki ulaşım yapılarının girişlerindençıkışlarına kadar yapılan hareketler boyunca elde edilen görünümler değerlendirildiğinde; Liman dışındaki ulaşım yapılarında farklı ve özgün bir görünüm olmadığı, limanda ise tarihi binalardan ve doğal çevreden kaynaklı görünümlerin etkileyici olduğu görülmüştür. Fakat limanda yapılan düzenlemelerde tarihi binalar ve yeni binaların bütün olarak ele alınmadığı belirlenmiştir. Dolayısıyla ulaşım yapılarının hareket halinde de sunduğu görünümlerin imaj değeri açısından zayıf olduğu sonucuna varılmıştır (Şekil 4). 
Tablo 1. Trabzon Otogarı bina - Yakın çevre bütününde görsel analizi

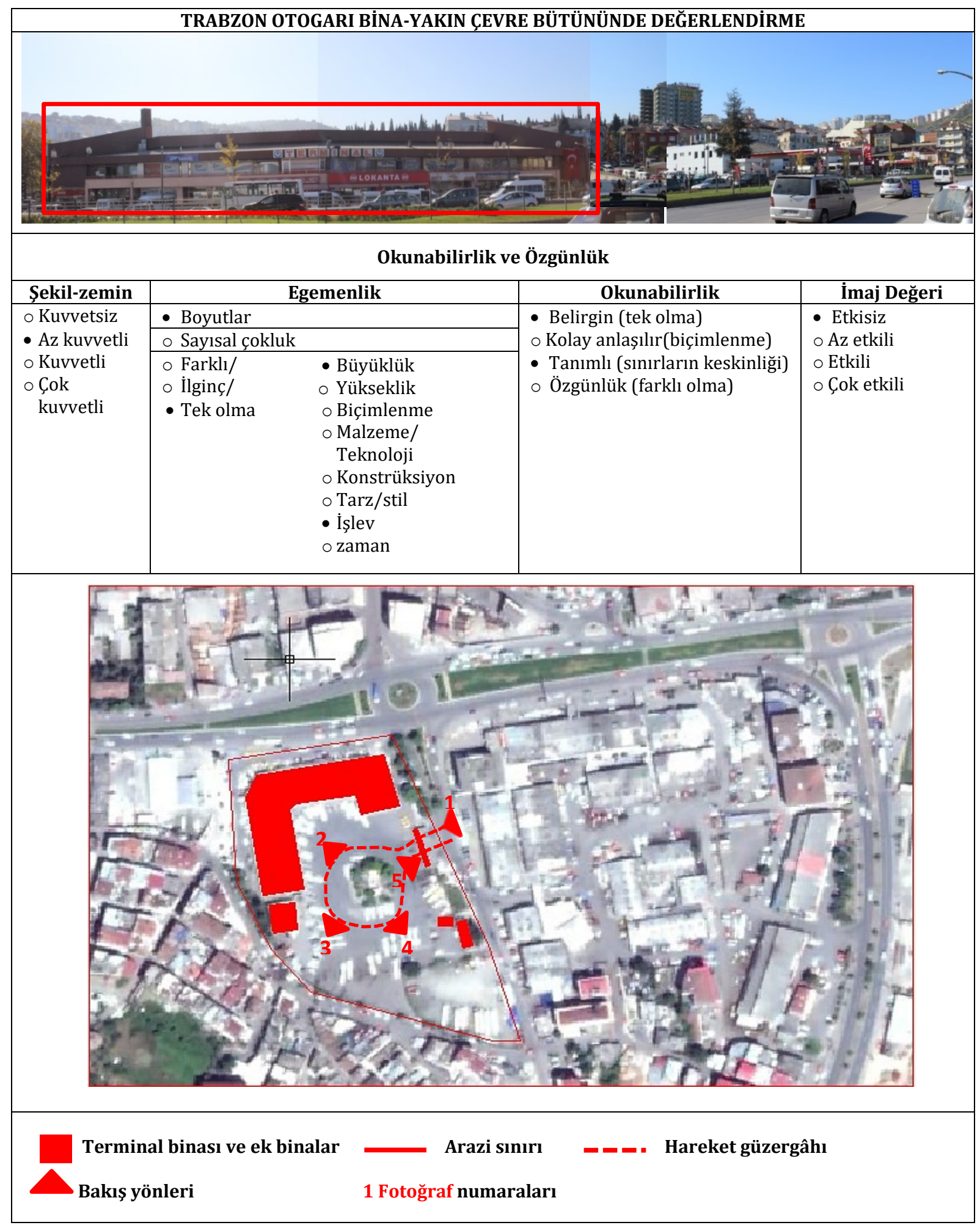


Tablo 2. Trabzon Otogarında hareket boyunca görünümler

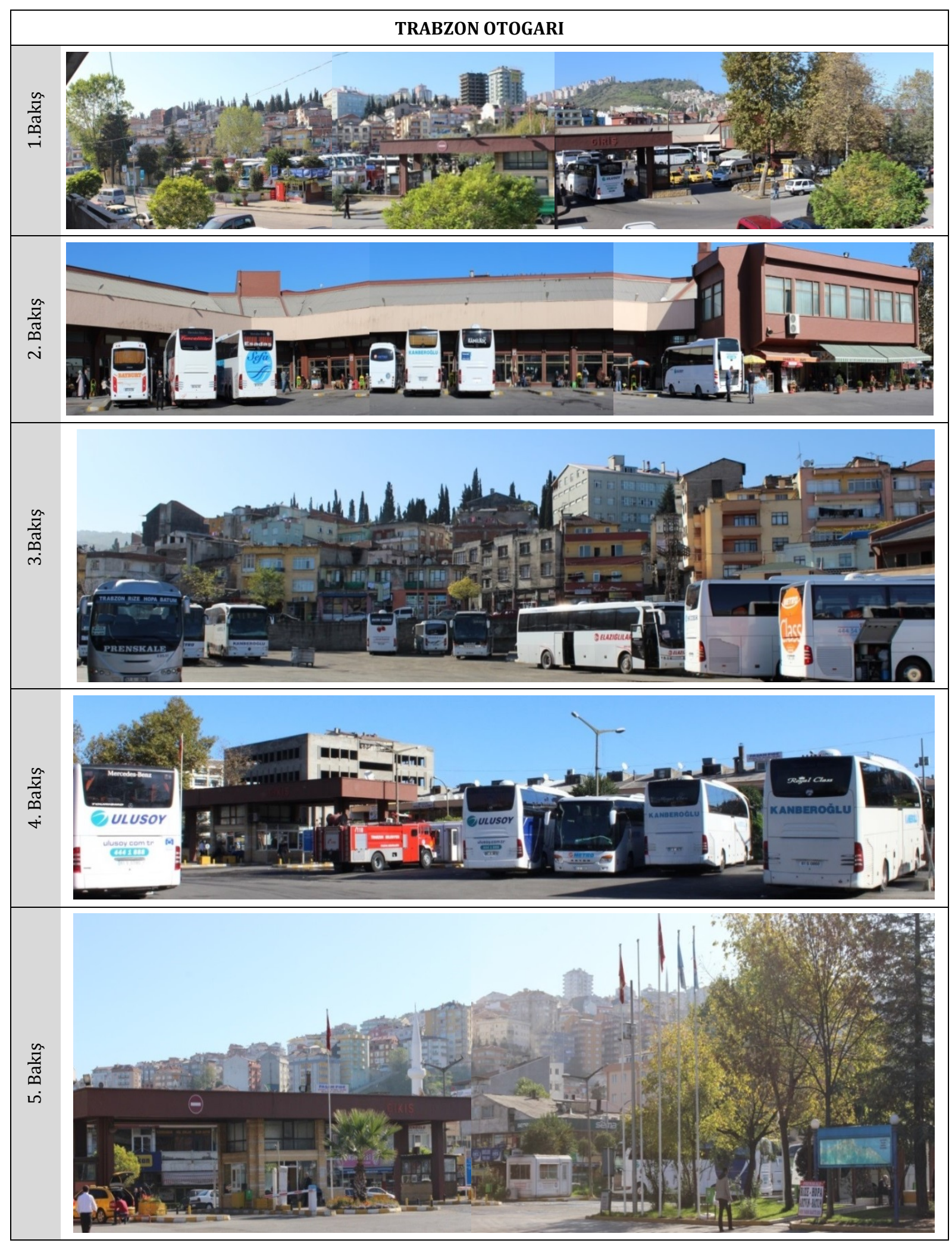


Tablo 3. Trabzon Limanı - Yakın çevre bütününde görsel analizi

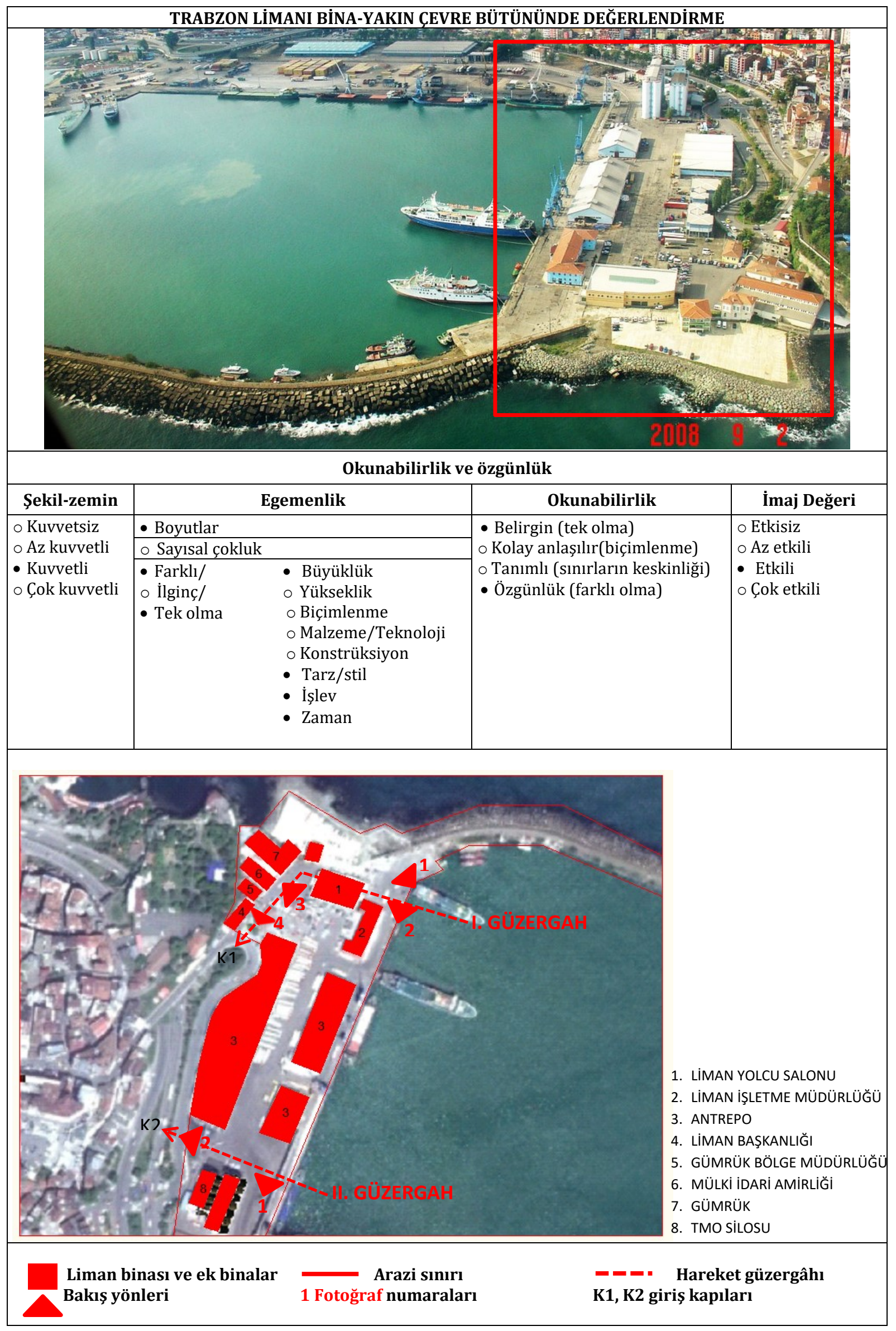


Tablo 4. Trabzon Limanında hareket boyunca görünümler

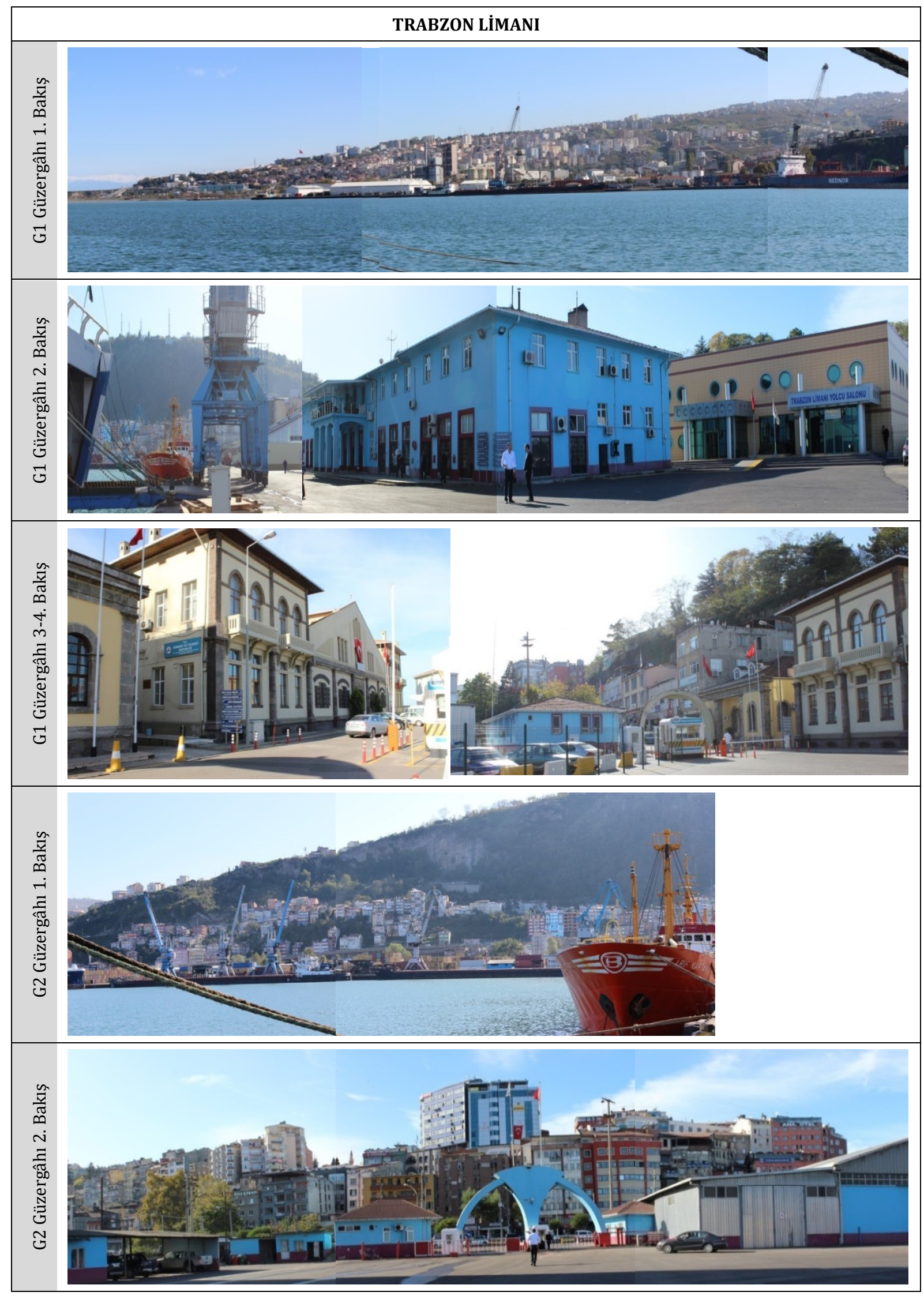


Tablo 5. Trabzon Havaalanı - Yakın çevre bütününde görsel analizi

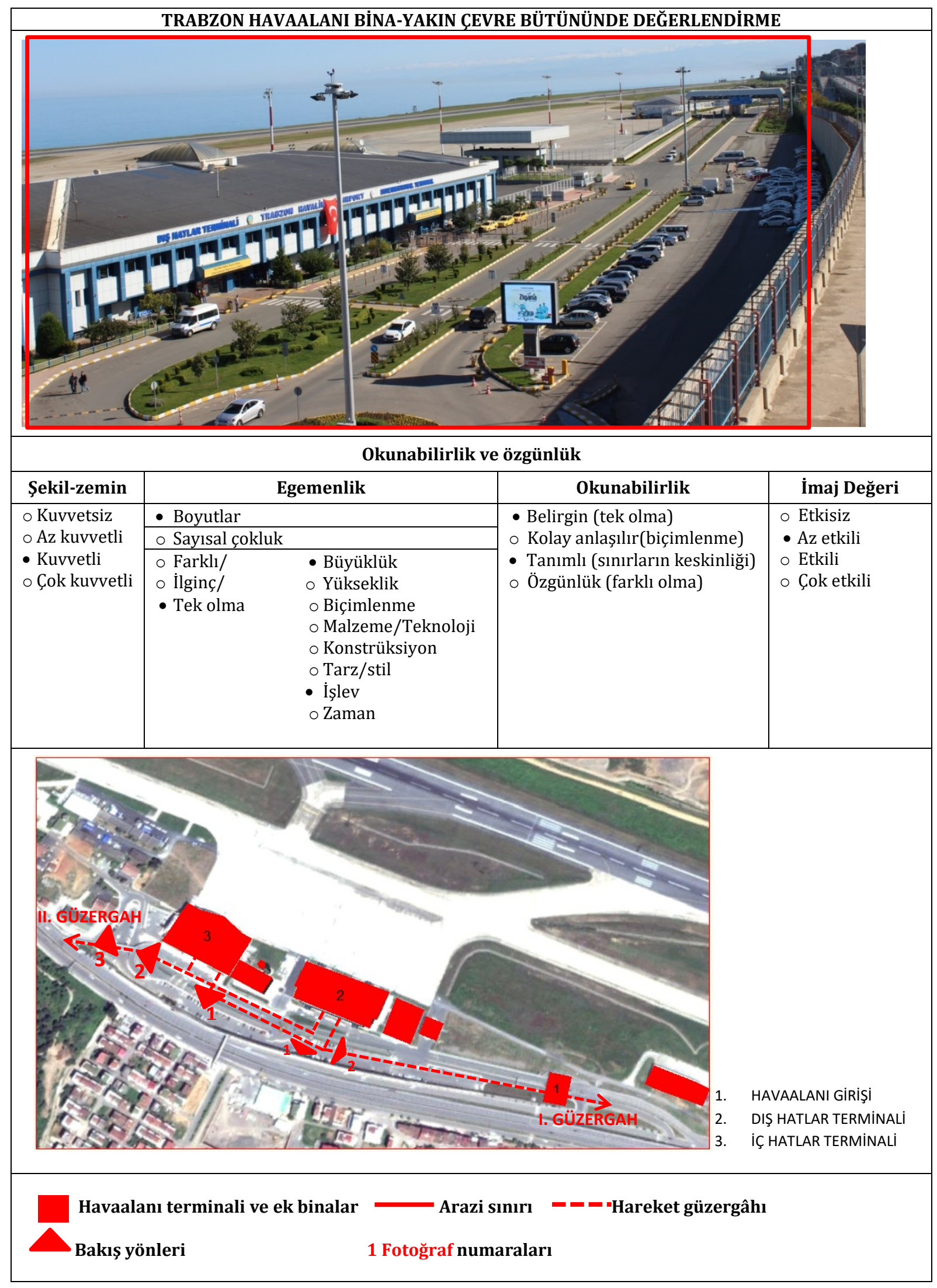


Tablo 6. Trabzon havaalanında hareket boyunca görünümler

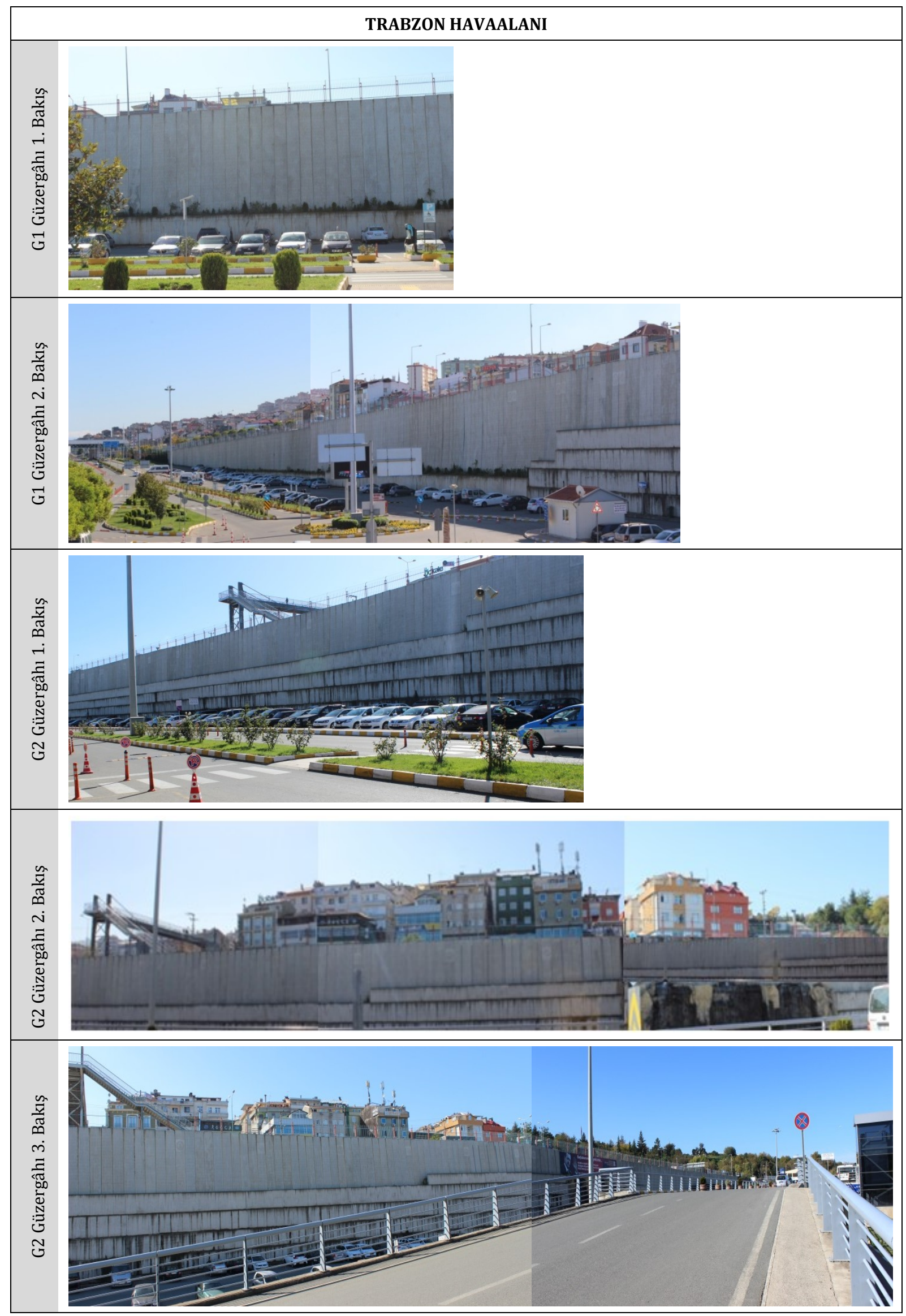



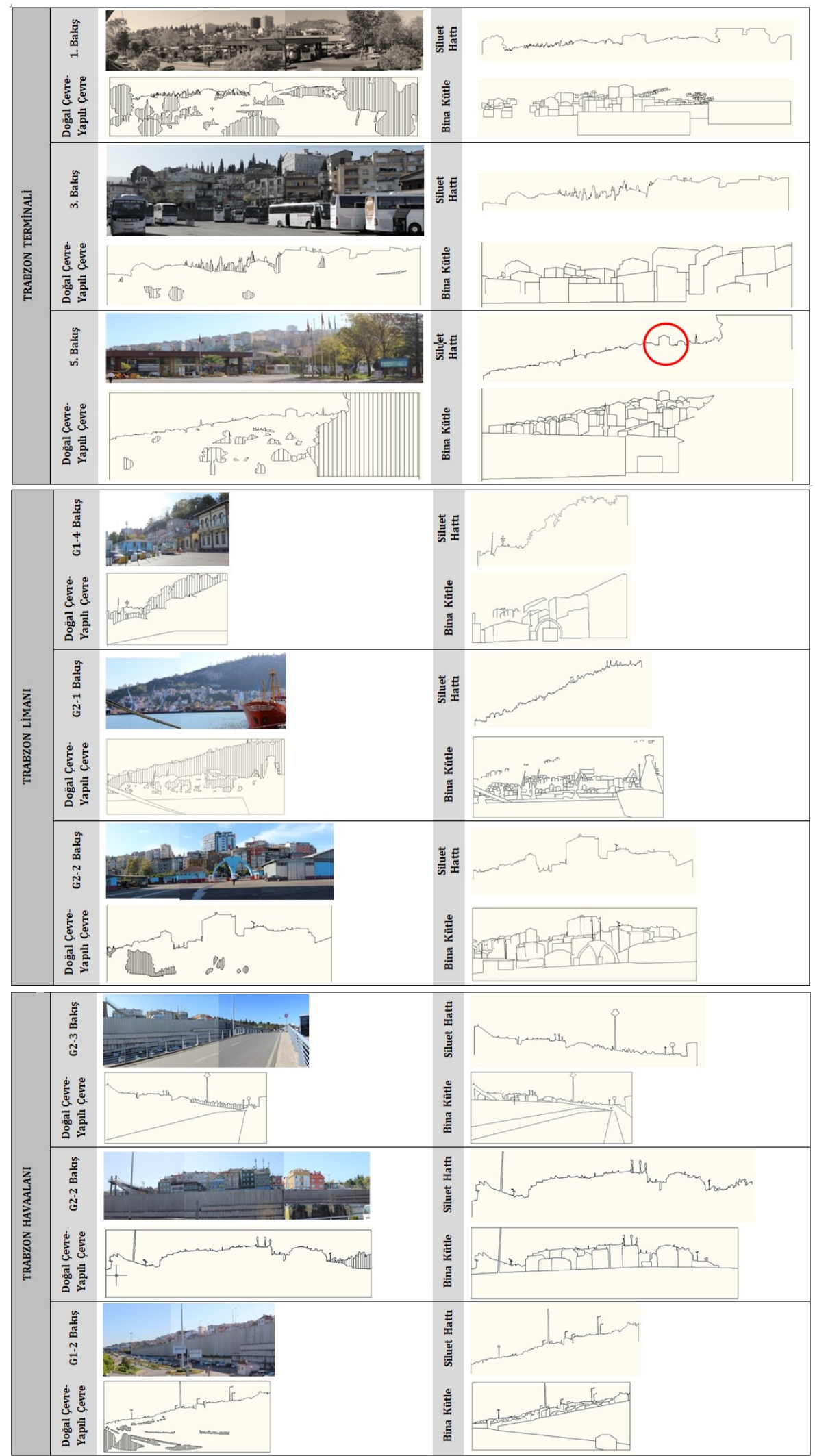

Şekil 4. Hareket boyunca elde edilen görünümlerin analizi

\subsection{Kullanıcı Tarafından Ulaşım Yapılarının Değerlendirilmesi}

Ulaşım yapılarının kentin yoğun kullanılan hareket aksları olan ana yolların üzerinde yer almaları ele alınan nitelikler arasında "algılanabilirliği" öne çıkarmıştır. Özelikle yolla ve doğal bağlamla güçlü ilişkisi nedeniyle havaalanı algılanabilirliği en yüksek ulaşım yapısı olmuştur. Havaalanı egemen, dikkat çekici ve kalıcı bulunmuştur. Algılanabilirlikten sonra terminal binasında egemenlik ve kalıcıllk kaliteleri limanda ise kalıcılık ve dikkat çekicilik kaliteleri ön plana çıkmıştır. Buna rağmen tüm bu kalitelerin etkileri zayıf bulunmuştur (Şekil 5). 


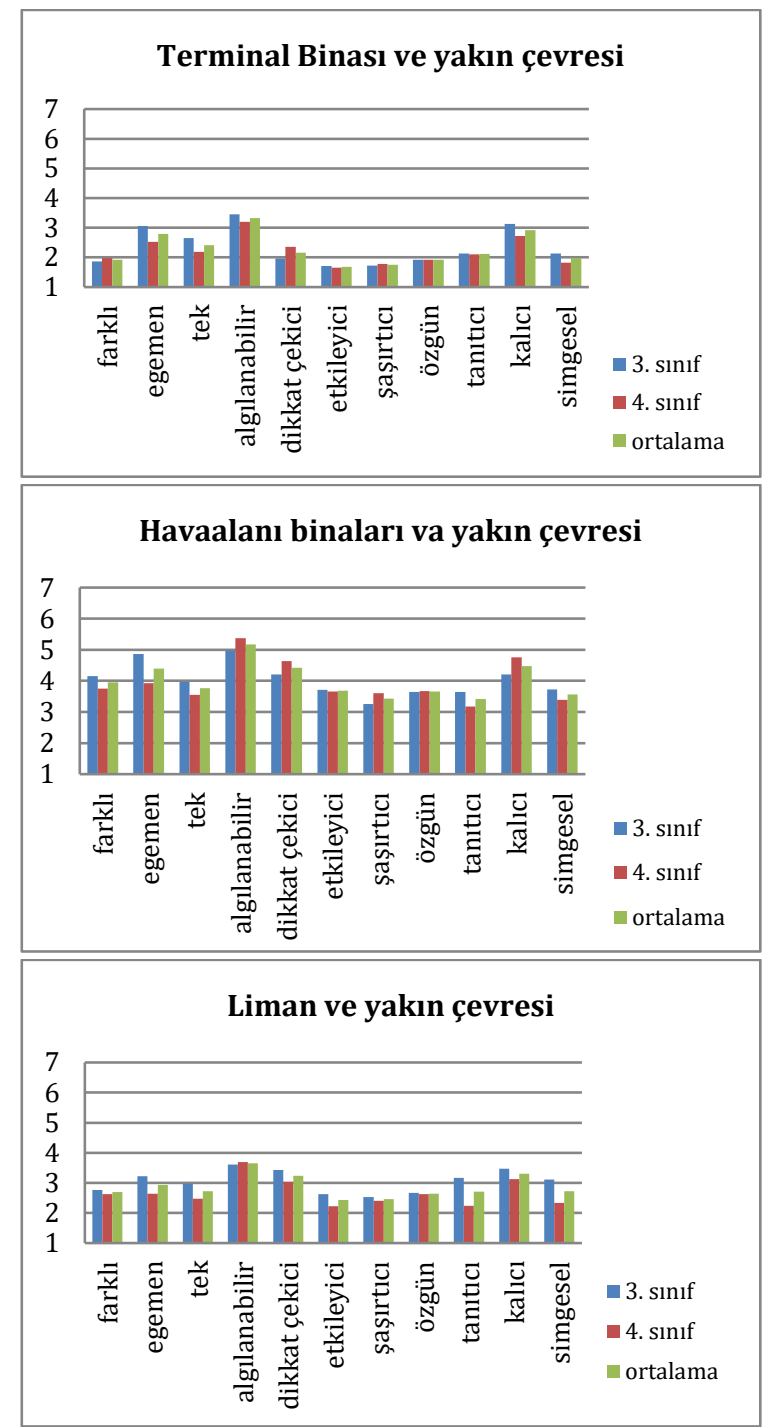

Şekil 5. Trabzon Ulaşım yapılarında kullanıcılar tarafından değerlendirilmesi

$\mathrm{Bu}$ değerlendirmeyi destekler biçimde kullanıcıların ulaşım yaplarına ilişkin sözlü ifadeleri değerlendirildiğinde;

Trabzon Terminali konumu gereği kolay ulaşlabilir bulunmuştur. Çok iyi algılanmadığı belirtilmiştir. Terminalin yakın çevresi düzensiz ve kullanışsız bulunmuştur. İmaj değeri olarak yerel bir kimlik taşımadı $\breve{l}$, biçimlenme olarak ise bakımsız, sıradan olduğu ve yerel kimliği yansıtmadığı tespit edilmiştir.

Trabzon Havaalanı'nın kolay ulaşılabilir olmasının ve deniz kenarında konumlanmasının önemli bir fark oluşturduğu, havaalanının karşısında yer alan üniversitenin havaalanına bir değer kattığı belirtilirken yolun altında kalması nedeniyle binaların çok iyi algılanmadığı ifade edilmiştir. Bölgede önemli bir havaalanı olmasına rağmen biçimsel özellikler açısından da sıradan olarak değerlendirilmiştir.

Trabzon Limanı'nın kolay ulaşılabilir olması olumlu bulunmuştur. Trabzon'un tarihi kimliğinde liman kenti olma özelliği taşımasına rağmen şu anki limanın bu kimliği desteklemediği belirtilmiștir. Tarihi binalar ve yeni yapılan binaların bütünlük içinde olmadığı, gelen yolcuların yaptığı giriş çıkış hareketleri boyunca limanın sahip olduğu bu özgünlüğü kullanamadıkları, niteliksiz kent görünümleriyle karşılaştıkları belirtilmiştir. Ayrıca sanayi, yük limanı ve yolcu limanı işlevlerinin bir arada olmasının olumsuz olduğu, görüntü kirliliği yarattığı belirtilmiştir. Ayrıca limanın kentin önemli seyir alanlarından biri olan Boztepe gibi yerlerden etkili göründüğü dolayısıyla imaj potansiyelinin yüksek olduğu belirtilmiştir.

Havaalanı; "Indikten 5 dakika sonra evinde olmayı herkes ister"

"Havaalanı şehrin merkezinde yer alması itibariyle ulaşım bakımından oldukça avantajlı deniz kenarına konumlandırılmış olması da ayrıca gürültü olarak ta insanı etkiliyor. Karşısındaki üniversiteden dolayı olan yeşillikler de Trabzon'u yansittyor."

"Sıradan bir havaalanı, tek güzel yanı deniz kenarında olması, deniz manzaralı olması"

"Havaalanının tek farkı kampüsten uçakları görebiliyor olmanız onun haricinde siradan"

"Yolun altında kaldığı için mimari gözükmüyor ..."

"Karadeniz bölgesinin sık kullanılan bir havaalanı olmasina ră̆men siradan”

Terminal; "Terminal bulunduğu yol üzerinde trafiği engellemesi yanında şehir içinde olması ve ulaşımın kolay olması iyidir. Aynı zamanda çok karmaşa var."

"Terminal şehrin içinde kaybolmuş bir görünümde..."

“...terminalin çevresi gayet düzensiz ve kullanışsız”"

"Trabzon terminali hiçbir şekilde Trabzon mimarisini yansitmıyor. Çünkü şehrin sanayi bölgesinin kurulduğu bir yerde yabancı bir insan geldiğinde Karadeniz havası almak istiyor...."

Liman; "Şehrin merkezinde olmasına răgmen Trabzon şehrinin en karmaşık yerine çıkıyor."

“... özellikle yolcu gemilerinden çıkan yolcuların yaptığ çıkış kapısının konumlandırıldı ̆̆ yer otoyola çıkması bakımından oldukça vasat..."

“...içi dă̆ınık ve bakımsız Trabzon liman kentine yakışmıyor"

"Eski tarihi binalar insana güzel gelse de yapısal olarak tümüne bakıldiğında kötü bir görüntü Trabzon için”

“...limanın sanayi ile iç içe olması limana inen yolcular için kötü görüntü sergilemektedir.”

“... Binaların dizilimi karışık, ...şsehirle ilgili ilk izlenim yaratması açısından giriş çıkış bölümleri kişileri olumsuz etkilemekte..."

"Yük limanıla ortak alan içinde olması yolcular açısından eksi bir puandır.”

“...limanın Boztepe'den yukarıdan görüntüsü çok iyi””

\section{Tartışma ve Sonuç}

Trabzon ulaşım yapıları kent merkeziyle iç içe ve kolay ulaşılabilir durumdadırlar. Bu yapılar kent 
ulaşım ağıyla bağlantılı ve yoğun kullanılan kent içi ve kent dışı ulaşım akslarında konumlanmaktadır. Ayrıca bu yapılar kentteki eğitim, alışveriş, hastane, sanayi gibi işlevlerle ilişkili veya bağlantılı konumlarda yer almaktadırlar. Bu durum ulaşım yapılarının algılanabilirliklerini dolayısıyla imaj potansiyelini arttırmaktadır.

Biçimsel açıdan sıradan, yoğun ve çarpık yapılaşma içinde ise kaybolan bu yapıların imaj değerleri zayıf olmaktadır. Trabzon kentinin imaj değerini arttıran geçmişten günümüze bir liman kenti olma durumu ve alandaki mevcut tarihi yapılar imaj açısından potansiyel oluşturmaktadır. Fakat limanın ve çevresinin mevcut durumu yapının bu potansiyelinin kullanılamamasına neden olmuştur. Yapılacak liman düzenlemesinde bu kimlik değeri güçlendirilmelidir.

Trabzon ulaşım yapıları kente dair; biçim açısından bütünlük oluşturmayan, uyumsuz, kimlik açısından ise niteliksiz görünümler sunmaktadır. Siluetlerde ne hacimsel ne de oransal bir denge bulunmaktadır. Siluetlerde doğal çevre ve yapay çevre bütünlüğü bulunmamaktadır. Siluetlerdeki yapı boyutlanmaları arasında bir denge bulunmamakta, bina sinırları hatta biçimleri bile net bir şekilde okunamamaktadır. Bütün içerisinde kenti tanımlayabilmeyi sağlayacak işaret öğesi oluşturacak farklı bir biçimlenmeye de rastlanmamaktadır. Kısacası Trabzon ulaşım yapıları ve çevreleri; günümüzde genellikle her kentte rastlanılabilen özgün olmayan, okunamayan, kalıcılıkları ve ilk izlenim oluşturmaları açısından zayıf alanlar olmaktadır.

Trabzon ölçeğinden yola çıkılarak genellikle çoğu kentlerdeki ulaşım yapıları tasarımdan malzeme seçimine kadar kentlere özgü ayırıcı nitelikler taşımamakta, diğer ulaşım yapılarından ayrılmalarını sağlayacak etkili bir imajları bulunmamaktadır. Ulaşım yapıları, kent imajı açısından kolay anlaşılamayan karmaşı okunaksı çevreler sunmaktadır.

Ulaşım yapıları kente dair ilk izlenimlerin oluşturulduğu yapılar olmaları nedeniyle önemli mekânlardır. Bu nedenle ulaşım yapıları yakın çevreleriyle birlikte bir bütünlük içinde ele alınmalı ve incelenmelidir. Tüm bunların yanında ulaşım yapılarının biçimlenmesinde estetik ve işlevsel kaygıların yanında farklı, tanıtıcı ve kente özgün olma özelliklerinin kazandırılması da önem taşımaktadır. Gerek kent morfolojisinde gerekse kent imajında etkin rol alan, kent kimliğinin güçlendirilmesinde önemli yeri olan bu yapılar, öncelikli müdahale alanları olarak değerlendirilmelidir.

\section{Etik Beyanı}

Bu çalışmada, "Yükseköğretim Kurumları Bilimsel Araștırma ve Yayın Etiği Yönergesi" kapsamında uyulması gerekli tüm kurallara uyulduğunu, bahsi geçen yönergenin "Bilimsel Araştırma ve Yayın Etiğine Aykırı Eylemler" başlığı altında belirtilen eylemlerden hiçbirinin gerçekleștirilmediğini taahhüt ederim.

\section{Kaynakça}

[1] Türk Dil Kurumu. 2021. Giriş. http://www.tdk.gov.tr/ ( Erişim Tarihi: 25.01.2021).

[2] Lynch K. 1960. The Image Of The City. The MIT Press, England, 187s.

[3] Karagel H. 2010. Mülki İdare Sinırlarının Belirlenmesi İle İlgili Kuramsal Yaklaşımlar Ve Türkiye'deki Geçerli Uygulamalar. VII. Coğrafya Sempozyumu, 18-19 Ekim, Ankara, 96-106.

[4] Tekeli, İ. 1990. Bir Kentin Kimliği Üzerine Düşünceler. Kent Planlaması Konuşmaları. TMMOB Mimarlar Odası Yayınları, Ankara, 82-83.

[5] Çöl, Ş. 1998. Kentlerimizde kimlik sorunu ve günümüz kentlerinin kimlik derecesini ölçmek için bir yöntem denemesi. Mimar Sinan Üniversitesi, Fen Bilimleri Enstitüsü. Yayınlanmamıș Doktora Tezi, 334s, İstanbul.

[6] Bilsel, G. 2002. Kent Kültürü-Kültürel SüreklilikKimlik Sorunsalı Ve Yașanılası Kentsel Mekan Kavramı Üzerine. Kentleşme Ve Yerel Yönetimler Sempozyumu Bildirileri, 25-26 Ocak, Adana, 21-25.

[7] Çizgen, N. 1994. Kent ve Kültür. Say Yayınları, İstanbul, 159s.

[8] Yargıç, S. 2009. Küreselleşen kentlerde ikonik yapıların kentsel kimlik oluşumuna etkileri üzerine irdeleme. Yıldız Teknik Üniversitesi, Fen Bilimleri Enstitüsü, 140s, İstanbul.

[9] Norberg Schulz, C. 1980. Genius Loci: Towards A Phenomenology Of Architecture. Rizzoli, New York, $216 s$.

[10] Eraslan Yayınoğlu, P. ve Susar, A.F. 2008. Kent, Görsel Kimlik ve İletişim. Umuttepe Yayınları, İzmit, 189s.

[11] Lang, J. 1987. Creating Architectural Theory, The Role of The Behavioral Sciences İn Environmental Design. Van Nostrand Reinhold Int. Ltd., New York, 278s.

[12] Berlyne, D.E. 1960. Conflict, Arousal And Curiosity. Mcgraw-Hill, New York, 368s.

[13] Jacobs, A.B. 1993. Great Streets. MIT Press, Cambridge, 331s.

[14] Bentley, I. 1993. Responsive Environments: A Manual For Designers. Butterworth Architecture, Oxford, 151s.

[15] Nasar, J.L. 1998. The Evaluative Image of The City. Sage Publications, United States, 182s.

[16] Carmona, M., Heath, T., Oc, T. ve Tiesdell, S. 2003. Public Places-Urban Spaces: The Dimensions of Urban Design. Architectural Press, Oxford, 311s. 
[17] İller Bankası. 1968. Trabzon Kentinin Tarihsel Yapısı ve Gelişimi Trabzon Analitik Etüdler 19671968. Ankara.

[18] Bıjışkyan, P. M. 1969. Karadeniz Kıyıları Tarih ve Coğrafyası 1817-1819. Edebiyat Fakültesi Basımevi, İstanbul, 132s.

[19] Aysu, E. 1982. Trabzon Kenti Planlama Çalışmaları. Türkiye Birinci Şehircilik Kongresi, Kongre Tarihi, Ankara.

[20] Özbilen, A. 1996. Havada Suda ve Görüntüde Kirlenme Trabzon İli Kıyı Yönetimi. Trabzon Vakfı, Ankara, 101-114s.

[21] Dilâver, S. 1987. Tarihçesi ve Tarihi Yapılarıyla Trabzon. Trabzon Dergisi, (1), 12-20.

[22] Bryer A. ve Winfield D. 1985. The Byzantine Monuments And Topography Of Pontos. Dumbarton Oaks Pub Service, Washington, 394.

[23] Usta, V. 1999. Anabasis'ten Atatürk'e Seyahatnamelerde Trabzon. Serander Yayınları, Trabzon, 268s.

[24] Tuluk, Ö.İ. ve Düzenli, H. İ. 2010. Trabzon Kent Mirası: Yer-Yapı-Hafıza. Klasik Yayınları, Trabzon, $517 s$.

[25] Anonim, 1997. Trabzon Ylllı̆̆ 1997. Trabzon Belediyesi Yayınları, 21s., Ankara.

[26] Demirci E., Köse E. ve Değerli B. 2000. Trabzon Limanının Benzetimle İncelenmesi. KTÜ Araştırma Fonu, Trabzon.
[27] Çiğdem, S. 2007. Eskiçă̆ 'da Trabzon Limanı: Askeri ve Ekonomik Yönden Gelişimi ve Doğu-Batı İlișkilerindeki Rolü. Atatürk Üniversitesi Sosyal Bilimler Dergisi, 12, 10.

[28] Anonim. 2015. Trabzon Limanı Alport. http://www.Al-Port.Com/ (Erişim Tarihi: 01.12.2019).

[29] Berber, M. 1992. Trabzon alt bölgesinin sosyoekonomik analizi-uygulamalı bir yaklaşım. Karadeniz Teknik Üniversitesi, Fen Bilimleri Enstitüsü, Yayınlanmamıș Doktora Tezi, 282s, Trabzon.

[30] Anonim. 2021. Trabzon Terminali. http://www.Trabzonkultur.Gov.Tr (Erişim Tarihi: 25.02.2021).

[31] Anonim. 2021. Trabzon Havalimanı. http://www.Dhmi.Gov.Tr (Erişim Tarihi: 25.02.2021).

[32]. Anonim. 2021. Trabzon. http://www.earth.google.com (Erişim Tarihi: 25.02.2021).

[33]. Anonim. 2019. Trabzon Limanı. http://fotografligezirehberi.com/karadeniz_gezi_reh beri/trabzon_liman_img_5989 (Erişim Tarihi: 01.12.2019).

[34] Aydınlı, S. 1992. Mimarlıkta Görsel Analiz. İTÜ Mimarlık Fakültesi Baskı Atölyesi, İstanbul, 66s.

[35] Öymen Gür, Ş. 1996. Mekan Örgütlenmesi. Gür Yayıncllık, Trabzon, 280s. 